\title{
The Necessary Impossibility: Dynamics of Identity Among Young People of Different Backgrounds in Vienna
}

\author{
Hakan Gürses \\ University of Vienna
}

Barbara Herzog-Punzenberger

International Centre for Migration Policy Development

Karl Reiser

University of Vienna

Sabine Strasser

University of Vienna

Dilek Çinar

European Centre for Social Welfare Policy and Research

Identity, the key term during the last two decades in social sciences, is employed for different, even opposite purposes. On the one hand, there are liberal aims claiming social recognition, which usually are summarized under the term politics of identity. On the other hand, there are social movements and conceptions, the objectives of which are diametrically opposed to emancipatory ideas, and which encompass nationalisms, ethnopluralism, cultural fundamentalism, differential racism, and xenophobia.

In this field of tensions this contribution is focusing on narratives and strategies of identity among young people in group discussions. Encounters among youth from different cultural, ethnic, and social contexts and with different expectations produce diasporic public spheres, which are neither predominantly emancipatory nor fully controlled, but rather emerging and therefore contested.

In our theoretical reflections we challenge common dichotomies and main models of identity; in our empirical approaches we examine the topography and the dynamics of identity as well as "situated hierarchies" of different sources of identity.

Identité, mot clé des sciences sociales des deux dernières décennies, est un mot utilisée à des fins différentes et même opposées. D'un côté, les visées libérales réclament la reconnaissance sociale, laquelle se résume habituellement par le vocable politique de l'identité, de l'autre, les conceptions et les mouvements sociaux dont les objectifs sont diamétralement opposés

Key words /Mots-clefs: identity/identité; migration; minorities/minorités; youths/jeunes; Austria/Autriche

๑) 2001 by PCERII All rights reserved. / Tous droits réservés.

ISSN: $1488-3473$

JIMI/RIMI Volume 2 Number/numéro 1 (Winter/hiver 2001):27-54 
aux idées d'émancipation et qui comprennent le nationalisme, l'ethnopluralisme, le fondamentalisme culturel, le racisme différentiel et la xénophobie.

Dans ce champ de tensions, le présent article porte surtout sur des récits et des stratégies d'identité exposés par de jeunes gens dans des discussions de groupes. Les rencontres de jeunes venant de contextes sociaux, ethniques et culturels différents et ayant des attentes différentes produisent des sphères publiques diasporiques, qui ne sont ni à prédominance émancipatoire ni pleinement contrôlées, mais plutôt émergentes et par conséquent contestées.

Dans nos réflexions théoriques, nous remettons en question des dichotomies communes et les principaux modèles d'identité; dans nos méthodes empiriques, nous examinons la topographie et la dynamique de l'identité ainsi que les "hiérarchies localisées" des différentes sources d'identité.

\section{Introduction}

The member states of the European Union have much in common: a European Parliament, a European currency, a supra-national legislative body, and a common external border. This state of affairs is linked with ancient patterns of community building, namely, the strategies of inclusion and exclusion that shape and consolidate nation states. As a result we can observe ongoing processes of redefining the Self and the Other. In most European countries the present political agenda conveys two ambivalent objectives: to combat increasing racism on the one hand and to stop "overforeignization" (Überfremdung) through immigration on the other. It is in this context that the term identity has become topical during the past two decades. Its use, however, has been varied and at times contradictory. The politics of identity serve disparate political agendas among which are those to do with the politics of emancipation and equal rights (Young, 1990; Gutmann, 1993). This concern is reflected in strands of theory and research where the relationship between identity and politics has become a central focus of inquiry. Such thematic fields are, for instance, the third generation of human rights, which are understood as cultural rights (Bielefeldt, 1998); the role of cultural rights in debates of multiculturalism in immigrant societies (Kymlicka, 1995; Bauböck, 1998; Zolberg, 1996; Çinar, 1996); or the theories of the subject in cultural studies (Lutter \& Reisenleinter, 1998; Grosseberg et al., 1992, 1994) and gender studies (Rich, 1984; Hill Collins, 1996; Mohanty, 1988; Brah, 1993). ${ }^{1}$

At the same time, those whose political objectives are to be found at the ultra-conservative end of the political spectrum have appropriated the term identity; that is, proponents of variously defined nationalisms, 
ethnopluralists, culturalist racists, and xenophobes. Indeed, xenophobia is seen by the extreme Right as a natural reaction to the perceived threat posed by immigrants to European identity (Balibar, 1990a; Taguieff, 1991; Stolcke, 1996; Çinar, 1999a, 1999b).

In other words, identities serve not only to craft positive self-images in order to achieve recognition, but also to construe negative images of the other through misrecognition and stigmatization (Taylor, 1993). These contradictory uses of identity can converge: simply because each construction of identity needs its constitutive other (Derrida, 1996), each gesture of inclusion is also a gesture of exclusion (Laclau, 1997; Mouffe, 1997). This is a dilemma with far-reaching implications: It requires caution against a "premature normativism" (Benhabib, 1999), which may lead to a use of identities as a priori "ready-mades" in scientific analyses. At the same time, however, it would be equally wrong to employ a kind of theoretical crypto-normativism and to suppress or reject the mobilizing force identities can have in people's lives. Put differently, it would be wrong if the analyst failed to see what he or she does not wish to be (Bauböck, 1996).

We aimed to explore this tension between the myth and reality of identity from the background of an empirical study conducted in Vienna. This study derived its data from an investigation into the identity processes of young people of different ethnic backgrounds. In what follows we outline the theoretical framework that shaped our inquiry and briefly discuss our research methods. Second, we summarize our empirical data, which were gained through several group discussions with young people. Finally, we draw a number of conclusions and suggest directions for further research.

\section{Theoretical Framework}

\section{Decentring the Subject}

Despite a widely held assumption, the criticism of modernism is not just the product of postmodernism. For theories in which a contextualized subject replaced the idea of a rational, autonomous, transcendent, and sovereign subject emerged in the late 19th century (Gürses, 1996; Habermas, 1985). These theories suggested that socioeconomic, historical, political, and gendered contexts determined and conditioned the subject. They were mostly of a philosophical, linguistic, psychoanalytical, and sociological provenance and were later radicalized in so-called structuralist, poststructuralist, and postmodernist schools of thought, 
which finally led to the "death of the subject" (Heller, 1995). In addition, there have been theoretical strands, which are closely related to political movements, thus prioritizing the collective rather than the individual or at least emphasizing the collective nature of the individual (as in Marxism, cultural studies, gender studies, or postcolonial studies). Hall (1994) identified five major theoretical shifts by which the subject was decentred and a "new logic of identities" emerged. Marx gave the subject its history; Freud the notion of the unconscious; Saussure a collectively defined language; Foucault a body penetrated by power; and finally the subject then became associated with culture and gender (Laclau, 1994).

The convergence of these various strands of theory with socio-political movements has produced the topicality of identity and led to the rise and proliferation of the politics of identity. However, there does not seem to be a strong contradiction between what Laclau (1994) has referred to as the universally proclaimed death of the subject on the one hand and the increasing interest in multiple identities on the other. As he puts it,

These two movements are not, however, in such a complete and dramatic contrast as we would be tempted to believe at first sight. Perhaps the death of the Subject (with a capital "S") has been the main precondition of this renewed interest in the question of subjectivity. It is perhaps the very impossibility of referring any longer the concrete and finite expressions of a multifarious subjectivity to a transcendental center that makes it possible to concentrate our attention on the multiplicity itself. (p. 287)

\section{Difference and Identity}

Since the 1970s new social movements (such as the movements for the rights of women, ethnic and linguistic minorities, homosexuals, or the disabled) have heightened public awareness of the symbiosis between identity and difference (Singer, 1997). ${ }^{2}$ Most of these movements are rooted in the experience of social and political discrimination. As a means of resisting discrimination these movements have positively redefined those social and cultural idioms by which they were marked out as different. They understand their specific experiences of discrimination as differences which are not shared by those who discriminate against them, that is, the dominant majority (Young, 1990). These differences provide the basis for their claims to a collectively shared identity. This 
involves reclaiming the subjecthood denied to them by manifold strategies of exclusion, nonrecognition, pathologization, and marginalization. For example, consider the repressive silencing of minority identities by the dominant majority; the representation of woman as a biological category; or the pathologization and criminalization of homosexuality. Identity politics thus come to the fore when public recognition of a self-determined different identity is claimed, or conversely when the promotion of a positive self-image is mobilized in order to transform stereotypes and to ensure one's political and social rights.

Some movements radicalize their politics of identity by means of essentialism. By making essentialist claims about their shared core identity, such movements effectively exclude differences among themselves. ${ }^{3}$ Whereas these movements tend to accentuate identity, other movements place more importance on the assertion of difference. Feminists in the United States and Europe, for example, have been concerned with a type of identity politics that might be defined as a permanent "differentiation of difference" (Klinger, 1995; Moore, 1994). ${ }^{4}$

Most of these concepts have been exposed to criticism. A variant of such critical assessment evolved in feminist theory in the early $1990 \mathrm{~s}$ and is explicit in the work of Butler (1991, 1997). Butler stated that identities can only be crafted as a resultant of mechanisms of power and, moreover, that processes of identity are also processes of power. In her estimation, feminism was wrongly based on the assumption of a preconceived identity of woman; to combat this error, feminists should build different political alliances and become more aware of their similarities and differences. This deconstruction of identity reversed several theoretical canons. Among these was the assumed difference between "natural" sex and "cultural" gender, as well as the idea that difference equals resistance against powerful discourses of universality. However, Butler's critical stance also met with rejection. Some critics felt that her position meant the end of political representation and as a consequence the end of feminism as a political movement (Benhabib et al., 1994).

Thus the politics of identity carries its own risks. That is, essentialist perspectives on identity may lead from emancipatory ideals to reactionary politics, and non-essentialist views may develop into an interminable focus on differences or become entrapped in radical criticisms of identity. Two debates concerning identity and difference have been of particular significance for the study presented in this paper: (a) the philosophical 
debate about essentialism and constructivism, and (b) the anti-essentialist conceptions of identity as they have been shaped in theories of culture, gender, and postcolonialism.

\section{Essentialism versus Constructivism}

Philosophical debates on essentialist versus constructivist standpoints (von Foester et al., 1997; Haraway, 1995) have been revived over recent years and become increasingly controversial (Ditrich \& Radtke, 1990; Çaglar, 1990, 1997). This controversy has contributed to the necessary challenge and critical reappraisal of seemingly stable categories such as ethnicity, culture, identity, and difference. However, to cast the essential and the constructed in a strict dichotomous mould can impede constructive thought. This point has been made in a number of recent publications, which attempt to mediate between these concepts. Benhabib's (1999) critique is particularly fruitful in this context. She identifies the dangers of essentialist theories of identity and demonstrates the shortcomings of the constructivist argument. In her assessment constructivism presents a threefold problem:

1. Constructivism cannot explain why individuals view differences of identity in an essentialist fashion.

2. Constructivism cannot provide reasons for those "cultural bits and pieces" social movements select from a range of possibilities; nor can it clarify which problems of identity these selected cultural aspects are to solve.

3. In short, constructivism can identify contingencies but not coherences. (p. 27, translated from the German)

In using the methodological metaphors of observer and participant Benhabib makes clear that theoreticians act as observers and therefore tend to register identities as construed entities. She suggests that a participant's position is inevitably different. For participants in a social movement that seeks recognition, it is precisely the belief in an essentialist identity that motivates them. ${ }^{5}$ It is therefore necessary, she argues, to take on board both perspectives in contexts of research.

\section{Hybridity and Intersections}

Identities are increasingly linked to processes of globalization. This is 
partly a reaction to a seemingly paradoxical yet parallel development: the dissolution and shifting of national boundaries on the one hand and the rise of local, often violent chauvinisms on the other. Geertz (1996) suggests: "cosmopolitanism and provincialism are no longer contradictions, they are related and reinforce each other" (p. 69). Hall (1994) has a similar dynamic in mind when he states that the dialectic of the global and the local creates "new ethnicities."

In addition, much of the theoretical literature claims that globalization has led to the fragmentation, deterritorialization, and hybridization of identities. Beck(1998) suggests "we are all global players" in the identity game and finds that people everywhere are increasingly prepared to accept difference and to participate in a "Babylonian world society" (p. 45). ${ }^{7}$

Theories of hybridity reject the notion of homogeneous, uniformly determined identities and subscribe instead to notions of heterogeneity and fragmentation (Hall, 1994; Lutter \& Reisenleitner, 1998; Webner \& Modood, 1997). Feminist and postcolonial theories promote a model that highlights the intersections of different subject positions. These become manifest in the often cited triad of race, class, and gender, according to which people assume their multiple identities. ${ }^{8} \mathrm{~A}$ close reading reveals, however, that despite considerable overlapping there is a marked difference between the concept of hybridity and the notion of intersections (Haraway, 1995; Braidotti, 1994; Friedman, 1997; Räthzel, 1999). The intersection model implies an analytical procedure. That is to say, composite identities are disentangled and their disparate categories (sections) such as gender, culture and class are exposed. The hybridity model, on the other hand, implies a synthetic procedure: It emphasises a more general term of culture that cannot be reduced to its component parts. In other words, the hybrid state accounts for a mixture of different cultural identities (Werbner, 1997).

As a result, both theoretical models give rise to different sets of questions and consequential problems. The theory of hybridity does not explain whether the phenomena it describes are descriptively or normatively understood. In other words, are the new ethnicities really as multiple and fragmented as they are presented, or are they rather expected to be that way? If identities in our globalized times are indeed hybrid, how do we explain the enormous power of interpellation (Gürses, 1994) exercised by national or religious identities?

In theories of intersection different subject positions are not derived from the same field (culture) but from different fields. The list of 
overlapping and mutually intersecting subject positions is long; it includes not only the triad of race, class, and gender, but also nation, religion, culture, sexual preference, and others. At the end of this list we usually find the indeterminate etc., which tells us that we may confidently add more (Butler,1991; Klinger, 1995). These apparently unlimited sources of identity are the Achilles' heel of the intersections model, because it provides no clues as to how these intersecting identities are ranked and ordered. To answer this question requires qualifying the "notorious etceteras," as Klinger puts it. She goes on to ask,

How many and which of the differences that may exist between individuals and groups are politically and theoretically significant? How can significant differences be distinguished from insignificant ones, and, what is more, who decides on the ranking of differences and according to which criteria? Is it possible at all to draw such boundaries; do such boundaries not again create an arbitrary impression of totality, against which the excluded differences (or rather the excluded people) could oppose? And is not the fact that the inventory of differences remains so often unspecified, rooted precisely in this dilemma? (p. 813)

The programmatic "etc" also serves to guarantee the academic sensitivity to difference. However, this may lead researchers to become wary of empirical analyses of identity. They may feel that the unavoidable selection of a few differences for the sake of their study may reify or rigidify these differences as categories. But in fact more empirical studies on the ranking of intersecting identities are needed. Only such research can eliminate the shortcomings of the intersections model, which is otherwise the theoretically more plausible of the two.

\section{Concepts Relevant to Research}

The debates on identity and identity politics briefly presented above have led us to consider further two notions relevant to this research. First, we take on board that the essentialist notion of identity is outdated and problematical (if not plainly wrong). However, contemporary debates have patently failed to address whether people experience their collective or individual identities as constructs (despite hybridity and diversity) or perceive identity in a coherent and essentialist fashion.

Second, the notion that people occupy different intersecting subject positions, which in turn are based on systems of difference, has provided 
a cogent model of identity. However, it fails to explain how these intersections operate. We therefore still lack satisfactory answers as to the topography and dynamic of identities.

With regard to the topography of identity, are there unlimited indiscriminate differences that generate the layers of identity? Or do we have a specific number of differences, produced in specific societies in specific historical contexts and thereby giving meaning to all or most identities? Further, are the various subject positions equal in relation to each other or do they interact according to a "situational hierarchy"?

On the dynamic of identity, when do specific sources or layers of identity become dominant? What happens at the intersections of subject positions? When are certain sources of identity activated and to what end? How are specific strategies of identification related to interpersonal relationships?

These are the questions that not only inform our research agenda, but also underpin this study on how processes of identity work. As a result, we are more interested in the how than in the why. Furthermore, we believe that identities are not approachable as static objects, but become manifest in narrative (Bhabha, 1990). Each narrative is located between collective language (langue) and individual speech (parole) (de Saussure, 1967). By focusing on narratives of the self we hope to understand processes of identity in their interpersonal dimension, as well as with regard to the dynamic between the individual and the collective.

"We have only made clear who we are!"9 (Group Discussions at the Youth Education Centre, Ottakring). In theYouth Education Centre (JUBIZ) in Ottakring (Vienna) young people from various countries such as Turkey, Austria, Macedonia, the Yugoslav Republic, Kuwait, and Brazil take an external secondary school course or participate in cultural and political activities. In their courses and initiatives more than 80 young people deal with a wide range of social, cultural, and political differences. Their encounters produce new social spaces (Appadurai, 1996, calls such spaces neighbourhoods), which are neither emancipatory nor entirely ruled by a regime of discipline; rather, these spaces are still undergoing construction and are being contested. We investigated the experiences of these young people in this context and the strategies they adopted. 


\section{Realization of the Research Method}

After we had presented our project proposal to the team of the secondary school and to the pupils of three classes, we spent several weeks in the JUBIZ in order to establish informal contacts. We used the time between lessons for personal chats and conversations, which afforded us invaluable informal data about the experiences and lives of the pupils. In the course of these conversations we further explained our interests and proposed research. As a result, the majority agreed to participate, and we organized eight group discussions ${ }^{10}$, of which four were selected for comparative analysis. Our fellow discussants were allowed to arrange the groups freely according to their own preferences. The discussions took place in the school building and lasted roughly two hours. In addition, we recorded our observations and obtained further information on the participants' demographic and legal statuses.

Ten men and 11 women between the ages of 15 and 21 took part in the four group discussions. More than half were born in Turkey and five were born in Austria. One of each was born in Macedonia, Bosnia, the Yugoslav Republic, Kuwait, and Brazil. Whereas some have been living in Vienna for more than five years, and had permanent residence permits, others had been here for fewer than three years, and even on completion of their studies their stay in Austria was not guaranteed.

To initiate an open discussion we clarified our intention to adopt a passive role during the conversation and then asked a number of catalytic questions that aimed at teasing out their specific experiences and relationship with the JUBIZ ${ }^{11}$. This gave them the opportunity to air their views about the courses and initiatives offered, as well as talk about their relationships with each other. During the discussion the research team only asked questions relative to the given topic in cases of a lack of comprehension. Probing questions were only asked when the discussion among the pupils themselves came to a halt. Finally, we only asked direct and pointed questions if topics we were interested in remained unaddressed. These questions concerned exclusively the everyday experiences of these young people. ${ }^{12}$

\section{Group Discussions: Narrated Processes of Identity}

Specific topics and interactions marked each of the four discussions under analysis. There were parallels as well as unexpected differences among them that reached beyond the topics or conversational styles. From an analysis of these common and different trajectories of narrative we were 
able to make inferences about the subject positions that were adopted and the meanings these positions had for processes of identity. We were particularly interested in situational hierarchies, in the narrative strategies by which people created alliances and drew boundaries, and how narrative structures changed.

\section{Spirituality and Rebelliousness: Four Young Women on Equality and Religion ${ }^{13}$}

This group discussion was particularly marked by homogeneity of gender and a difference of ethnic and religious backgrounds. Four young women spontaneously decided to come together for a discussion. Marija ${ }^{14}$ and Jelka were friends; both came from the former Yugoslavia; Aisha and Izabel were also friends; Aisha was a Kuwaiti but held an Iraqi passport; and Izabel was from Brazil. Jelka and Aisha declared that they were Muslims; Marija and Izabel were Roman Catholic. ${ }^{15}$ The residence permits of all four were fairly secure, but none carried an Austrian passport. The discussion among these young women was animated and at times controversial. The themes discussed ranged from leisure activities, neighbourhoods, and violence in the public sphere to gender relations and religion. In most cases Aisha suggested the themes, to which Marija responded controversially.

Replying to our initial question they discussed the little spare time the courses allowed and agreed that being a woman always meant less freedom and more restrictions. Whereas Aisha and Izabel lamented this situation, Marija actively resisted the restrictions she experienced. She claimed that she took control of her own time and did not bother about the course or about assisting her mother with housework. She preferred to play football instead. Izabel and Aisha indicated that they too were tired of staying at home, but ended up doing so most of the time.

Aisha: we come to school and we have no time .... We have English lessons until six o'clock and then we have to go home.... Only sometimes I go for a walk with Izabel ....

Izabel: I always stay at home and look after my sister.

Izabel's brother, however, cannot stay a minute at home, and sometimes he did not come home for days. Izabel sympathized with her mother's worries but insisted that her freedom was so much more limited than her brother's. Marija declared sympathy with Izabel's brother and agreed 
with his behaviour.

Marija: In our society it is the boys who are allowed to go anywhere, not the girls. But I still go even when my mother says "no" ...; I go ..., I don't stay very long, I come back after two or three hours.

The girls agreed on the disadvantages they had regarding being female, but they disagreed widely on matters of religion. However, it was not the religious affiliation with Islam or Christianity that separated or united them, but rather questions arising out of whether to accept or resist religiosity and parental values.

Aisha and Izabel tried to link different and seemingly contradictory subject positions; Marija, on the other hand, tried to dismiss one subject position in order to realize her claim to individual freedom.

Marija: I mean, I don't know er ..., there is a God and stuff but-I am a Roman Catholic but I don't go to church ...; I don't pray ... I hate religion.

Whereas Aisha and Izabel agreed on the value of some-even if different-religious norms, Marija argued in an impulsive and contradictory manner. Jelka seemed to seek new frames of orientation and refrained from making specific claims. Two diametrically opposed standpoints tended to impede the communicative exchange in this group: the mere normative declaration of belonging to a religious community on the one hand, and the actual practising of the faith with resultant spiritual experiences on the other. Each position drew on different sources of orientation, different sets of meaning, and different rules of conduct. In sum, how this group agreed and fixed boundaries was primarily rooted in the emancipatory needs of the participants, which some articulated in "mediating" and others in "rebellious" ways.

\section{Are all Doors Closed? Young People Between Reorientation and Deportation}

This group was homogeneous in terms of national origin and religion, but heterogeneous in terms of gender, ethnicity, and citizenship. All three participants were born in Turkey; they were between 19 and 20 years old and had lived fewer than three years in Austria. They all said they were Muslims. Yasemin and Sakip did not know whether they would be able to stay in Austria after having obtained the secondary school diploma, or once out of school whether they would be able to find employment 
there. Yavuz had been granted citizenship. From the beginning of our conversation, this group therefore addressed the issues of work and education.

Sakip: I have been ... in Austria for more than three years, then ... I wanted to find work. But I didn't get a [work permit].

Because his parents had six children and lived on a low income, Sakip was forced to work without a permit. He affirmed, For me all doors are closed. He also said that he felt like a second-class citizen. Yasemin lived in Vienna with her mother and three siblings; her father and another sister had remained in Turkey. She revealed, Ineither have a health insurance certificate nor do we get family allowance. In addition she did not have a residence permit for the following year. Here the impact of the Austrian juridical system on the lives of each marked the difference between the participants. In other words, it was not so much their positions and affiliations that separated them, but rather their different chances of access to work, education, and social rights.

In response to our question of how they spent their spare time, the three youths then discussed religion. Yavuz represented himself as a good believer who spent a lot of time in the mosque and had found many friends there. Sakip and Yasemin had not had such experiences. Rather, they were critical of the mosques and asserted that they were ruled by politics. The subject of religion also stimulated remarks about family and marriage, which in turn made the discussants erect boundaries between themselves. Sakip and Yasemin voiced an emancipatory view according to which the sexes should regard each other as partners; Yavuz, on the other hand, believed in traditional values, which implied that the wife should stay at home and look after the children. Yasemin, who claimed at first that she did not want to marry and have children, finally admitted, Religion is important for me, really ... I won't marry [into] another religion. Sakip, on the other hand, stated that he wished to marry and claimed that his wife's origin and religion did not matter to him as long as it was love that bound them. Even though Yasemin had a different opinion than that of Sakip, she believed that religion could be linked with emancipatory ideals. Whereas Yavuz adopted an unambiguous and orthodox position, Sakip and Yasemin were in search of suitable frames of reference and orientation. This discussion thus revealed that they were clearly making efforts to link different subject positions for the sake of emancipatory ideals, whereas Yavuz's traditionalist-separatist 
stance conveyed no uncertainty. The three viewpoints they raised about family planning and future lives referred to the plurality within Sunni Islam and highlighted the respectful ways these youths dealt with differences.

\section{Times, Languages, and Limited Chances}

All six participants in this discussion were from Turkey and had Turkish citizenship. There were, however, religious and ethnic differences among them: Four were Alevi Kurds and two were from a Sunni Turkish background; all were between 17 and 20 years old and had come to Austria just a few years before. Despite still having some language problems these youths were interested in this type of "political" discussion and participated in a lively and intellectually stimulating manner.

Moving on from their political and ethnic self-representations, the discussion revolved around comparative assessments between Austria and Turkey as well as between Alevi Kurds and Sunni Turks. Yeter, who was himself of Sunni Turkish origin, assumed the role of mediator: he relativized, differentiated, tried to reconcile differences of opinion, and contributed to a lengthy discussion about the meanings of political and ethnic affiliation. Despite minimal linguistic competence and a precarious legal status as foreigners, all participants concurred that social security, opportunities for education, and employment offered them the chance of a much better life in Austria than in Turkey. Interestingly, there was a general silence about the real likehood of their realizing these opportunities. By contrast, there was general assent on the necessity to improve their language skills.

Whereas the Kurdish youths condemned the ban on their mother tongue in Turkey, in Austria they complained about feeling linguistically insecure and unable to verbally defend themselves orally in German. Whereas competence in the dominant language in Austria indeed means better chances of integration and social improvement, in Turkey communication in the national idiom was enforced by the state but had little impact with regard to improving one's social position. The positive meaning the discussants gave to Europe in this context was surely more to do with hopes and aspirations than with actual experiences.

Baris: If you really want you can make it!

Despite their self-identification as Alevis (Kehl -Brodogi, 1989; Vorhoff, 
1995) the four Kurdish youths claimed to be atheists. They emphasized their distance from radical forms of religion, that is, from Islamic fundamentalism, which they blamed for their persecution. So an image of the enlightened and liberal leftist Alevis emerged set against the conservative fundamentalist Sunni Muslims. The political categories of left and right were expressed in the dichotomous terms of atheists/democrats and Muslims/fascists. Nevertheless, the discussants emphasized the importance of friendship with the other ethnic and religious groups and claimed that ultimately both groups belonged to Islam. Fundamentally, their criticism mainly targeted the Turkish government and state policies.

The recurring references to time and language mirrored the fears and aspirations Baris, Devrim, and Mehmet harboured. They voiced these issues not only in the context of the Kurdish-Turkish conflict, but also when addressing their career prospects as migrants in Austria.

Devrim: the problem is time; I have lost so much time, that's negative in my life ... I've lost five years. If I had stayed in Turkey I would have lost my entire life. Because I can't move up there (in Turkey), I cannot make a career ... because I am a Kurd.

The discussants expressed many of their experiences with discrimination in references to language and time. The period before emigration was understood as a "loss of time," the period in Austria was classified by a spell of time loss through language acquisition, and the time that lay ahead was constrained by certain objectives that had to be realized. Equally, the scarcity of time seemed to prevent desired social interactions and political aspirations from taking place. In sum, the situation between reducing loss and securing gain meant both risk and opportunity. The notions of time loss and speechlessness were not only ways of talking about marginalization in Turkey, but also of expressing the limited but desired opportunities in Austria.

The Kurdish teenagers described a situation of transition, which was not thought of in terms of culture. Rather, they related to a process of change from their political responsibility to a more self-centred individualism. Whereas the latter related to the pursuit of personal advancement in Austria, the former was more to do with an activity within a bounded ethno-religious group. While discussing these topics the participants neither linked nor separated different subject positions; they confronted them with each other as periodically fixed images. 


\section{Love Beyond Culture}

These conversations were held with a project group that had been formed in 1997, following an initiative of the JUBIZ. The young people who were active in this project were not only graduates of the secondary school courses, but also pupils and professional young people from all over Vienna. Those who participated in our discussions felt that the way we conducted the conversations came very close to their own style of meeting within the project.

The participants were between 15 and 21 years old; they were five women and three men, with Turkish, Serbian, Croatian, German, and Arabic as mother tongues. With one exception all were Austrian citizens or had permanent residence permits, and their knowledge of German was good.

The main cause for conflict during this discussion arose from the question of whether men and women had different interests with respect to romantic relationships. The discussants agreed that the sexes should be equal partners, but they differed in their views on how this should be put into practice. For example, whereas Can strongly objected to the idea that the portrait of his girlfriend might appear on the front page of a newspaper, Michaela held that it is generally terrible if someone can dictate to [his] partner what to do. Can responded by saying that it must be possible that she can tell me something and that I can tell her something. The right to make autonomous decisions was then contrasted with a notion of partnership, which might require the abandonment of individuality. Can expressed the belief that, If you enter a relationship you have ceased to be alone. He located this opinion within the framework of "cultural rules." He maintained that this view is very dear to him, because adherence to existing norms and traditions acted as a safeguard against losing his Turkishness.

Can: If I said: ... okay well she is so pretty and that is why she is being looked at, ... I would cease to be a Turk. I would be an Austrian then.

Whereas two women in the group defended their right to selfdetermination, two men-Can and Hassan-tried (albeit in different ways) to foster an understanding of their positions. Both came from a cultural background where Islam is the dominant religion and is often portrayed by Europeans as being abusive to women. Whereas Hassan tended to react less forcefully to the notion of cultural difference, Can endeavoured to make everyone understand these differences and claimed 
a right to his views. He rejected the idea that everything he had learned in Turkey was against women or against equality between the sexes. He wished to convey his reactions to such negative views and at the same time sustain his need to maintain certain principles and emotions.

It became clear that willingness to understand the others reached limits when everything that seemed dear and important should be abandoned. Thus the ogling of his girlfriend by Austrian males was angrily rejected by Can. The consequent critique voiced by the Austrian women did not target Can's rejection of the male erotic gaze, but they saw in his anger the desire for a hierarchical order of the sexes and for the continuation of male control over women. Here issues of hierarchy and control were frequently linked to Turkish or Arabic culture and education.

Notions and views to do with sexual relationships were represented as culturally different. The legitimacy of certain claims and principles turned into the legitimacy to claim the right to a different culture. Related to these claims, the love for one's partner then underwent a symbolic transformation and became the patriotic love of one's nation; consequently, such a love was not to be violated. Can referred to the Turkish flag and to notions of honour when he explained his ideas on relationships and slighted feelings. But instead of gaining an understanding from his fellow discussants, he met with outright rejection. He was accused of displaying "medieval" behaviour, stupidity, and an irrational disposition to violence.

Can, who repeatedly made his presence felt during this discussion, increasingly turned into a "Turkish man" in the eyes of the women in the group. He genderized the notion of honour by contrasting it with a weak form of masculinity, which he defined as rational, cold, profitminded, cowardly, and self-controlled. Moreover, whenever he made comparisons between violence, dominance, nationhood, and concepts of honour the young women interpreted this as talk about power. We understood that Can tried to learn from others without necessarily adopting their ways and he expected them to do the same. He insisted that his expectations and principles should be respected and dealt with rather than dismissed. He held that a contentious comprehension of an erotic gaze would simply disappear when everyone understood the relevant social codes and knew they were violating rules of behaviour. Such a problem only occurred when different views, experiences and interests met. Can insisted that everyone should make an effort to understand his concerns and cultural background, just as he tried to understand theirs. 
What "has been made clear"? 16

The discussions of these youngsters showed that they are in search of recognition and a sense of belonging in their social spheres. They arelike most young people who live in diaspora-repeatedly exposed to radical changes. Their social environment, their daily experiences, and sources of information are replete with challenging contrasts. They deal with these situations according to their previous experience and to what they have learned about right and wrong.

Group affiliation (e.g., men, Muslims, Macedonians) says little about how these young people live their daily lives; how they make decisions, form alliances, and draw boundaries. This realization has led us to ignore preconceived categories of identity such as gender, culture, or religion in our analysis. Instead we placed our main emphasis on the topography and dynamic of identity processes. From this shift of emphasis the following questions emerged.

Are we dealing with processes of conjunction and disjunction? Are differently rooted subject positions subjected to a new layering of identities? Is it thus a new topography of identities that emerges from already existing knowledge, from narrative and experience? Does this lead to a new, if temporary, fixing of identities? Do these indicate the arrangement of their movable components in this imaginary landscape? Are there patterns of hierarchization, which might be called orthodox, and others which might be called subversive or innovative (which does not necessarily mean emancipatory)? Can certain differences be extracted from an infinite chain of subject positions and become politicized or instrumentalized as new orthodoxies?

Furthermore, what does it mean when two young Catholic women discover that they have less in common than a Muslim and a Catholic woman (as seen in our first group discussion)? Marija clearly opposed Aisha's and Izabel's stated meaning of religion in their lives. Whereas Marija distanced herself because she felt religion threatened her liberty as a woman, Aisha and Izabel included religion in their desire to obtain equality in relationships with men, education, and employment. In this regard Aisha and Izabel did not view their faiths as obstacles to unity. To them their shared religious experience was more emotionally important than the difference between Christianity and Islam. In both cases religion was seen as partly constituting gender. Equally, all three of them felt disadvantaged as women and desired more recognition and freedom. Aisha and Izabel attempted to redefine gender within the framework of their faiths, or in other words, they tried to redefine their religion through 
transforming the relationship between the sexes. Marija, however, believed that the process of reforming gender relations was purely a secular matter. This made her strategy inherently different from that of Aisha and Izabel. However, while both positions converged in their critique of existing orthodox religious views on gender relations, their strategies of relating to partly new positions of identity diverged. This created a new dynamic and led to unexpected alliances and divisions.

What does it mean when two young Turkish men differ in their views of Islam and women's rights despite sharing religion, origin, and much of their educational and social background? In Austria both Sakip and Yavuz (in our second group discussion) were exposed to different forms of insecurity: Sakip had to struggle with residence permits and a de facto ban on employment; Yavuz's involvement with a public form of Islam exposed him to the negative stereotypes propagated by Western societies vis-à-vis the Muslim "other". Like Izabel and Aisha, Sakip tried to reconcile his faith with the notion of gender equality. He defined religion as an important but nevertheless private factor of life. ${ }^{17}$ Yavuz's aim was to take great care to maintain his belief, and he felt that religion determined the natural hierarchy between the sexes. For him religion was supreme to all other subject positions such as those defined by gender and nation. Sakip and Yavuz, in short, positioned themselves differently with regard to religion and gender and as a result produced different patterns and strata of identity. Thus these two young men who might be regarded as adopting the same identity due to shared gender, religion, and ethnic origin differed greatly in their attitudes to women.

What does it mean if four Alevi Kurds (in our third discussion) actually produce a shared opinion? It seemed that the priority they gave to their ethnic and religious affiliation determined all other subject positions they might have taken. This provided the baseline for their comparisons between Austria and Turkey and served as a denominator in terms of which past and present opportunities were evaluated. The religious term Alevi seemed to be an additional signifier of the ethnic term Kürt irrespective of the fact that not all Kurds are Alevis, and that Turks can be Alevis too. The views of the only woman in the group remained largely hidden, and the individual narratives were then turned into a collectively articulated opinion of the group.

What may be concluded when Can, who is an open-minded young man, equates his honour ${ }^{18}$ with reverence for national symbols and thus creates unexpected links between different indices of identity (in the fourth discussion)? His companion Hassan, who was also raised in a 
Muslim environment, understood his position but did not share it. Can (who had an Alevi girlfriend and insisted on his eclectic and therefore "liberal" ideas about gender relations, but who was nevertheless criticized in the group for discriminating against women) argued from the perspective of an involved participant. Hassan, on the other hand, simply commented and analysed while adopting the role of an external observer. Thus we had a situation where strategic essentialism and situational (constructivist) relativism met.

In sum, the group discussions made clear that it is important to examine the strategies these young people employ in crafting their identities, as they focus not only on difference but also on alliance and dominance.

\section{Conclusions}

At this juncture we offer some conclusions, which are presented in the form of hypotheses. These are followed by a brief discussion of the discursive strategies that repeatedly emerged in the discussions. Finally, we suggest some directions for further research in this field.

\section{Hypotheses}

The articulation of differences in society creates intersubjective contexts that we termed subject positions. These are sets of meaning in relation to which individuals orient themselves and legitimize their actions. We described these processes of orientation as processes of identity.

We argue that identity is not another name for the unified and homogeneous subject; neither can identity be thought of as a single subject position enclosed in a stable system. In a globalized world, people neither act nor legitimize their actions merely on the basis of one position of difference or with regard to a one-dimensional subjectivity. Identity, therefore, (whether individual or collective identity) always includes a variety of subject positions. These are variously defined as senses of belonging, affiliation, or membership; or in other words, they materialize in acts of identification with a collective, which is generally referred to in the literature as an "imagined community" (Anderson, 1998; Balibar, 1990b; Appadurai, 1996).

Processes of identity effect the "suturing together" of subject positions to a provisionally coherent assemblage. These processes of identity are determined by various social dynamics that range from power relations 
and the positioning of individual interests to struggles for recognition and distribution of societal resources. Thus in processes of identity people interconnect, suspend, and recombine subject positions in order to establish or dissolve boundaries (Barth, 1969).

Social actors who participate in processes of identity have a range of different subject positions at their disposal. However, this is not comparable to, say, going shopping, where a range of goods can be selected according to individual taste and put in a basket. With identities, the selection is restricted in two ways: first, the number of appropriate subject positions to choose from is always restricted. Some subject positions attain importance in certain societies during certain historical periods, whereas others lose their significance. For example, in most Western European societies the question of being a Protestant or a Catholic lost much of its relevance from the 17th century onward. The alliance between two of our discussants who both defined themselves as religious but belonged to different faiths provides a good example. Even those subject positions, which have remained crucial over an extensive period, have been represented differently in different social and historical contexts: gender-based subject positions serve as a good example here.

Second, different patterns in different historical and social contexts shape the situated suturing together of subject positions. Thus we see in the group discussions that those youths who defined themselves as Alevis found it quite natural to link gender with religion when talking about liberation. This can also be seen against the backdrop of contemporary Anatolian Alevism where gender equality and Islam are not seen as contradictions.

Despite diverse but limited possibilities of combination, the intersection of subject positions follows a "situational hierarchy"; that is, one subject position dominates and becomes the main axis along which other sources of identity are ranked and periodically subsumed. This occurred in many of our group discussions when individual positions were discussed and legitimized in relation to a single category such as gender or culture. ${ }^{19}$

It is within these restricted possibilities and interrelations that identities materialize, intersect, and lose effectiveness. Identities are relatively endurable; they are neither daguerreotypes nor disposable articles. 


\section{Discursive Strategies}

Most young people, especially those who had been in Austria only for a short while, ${ }^{20}$ tried to reconcile their identities with the new conditions in which they found themselves. This was done such that it did not affect the "content" but rather the "grammar" of their identities. Thus, for example, someone used the same content (such as the meaning of a foreign language) in different, if not contradictory, contexts in ways that changed its meaning. The Kurdish youngsters from Turkey differentiated between the foreign language at home and elsewhere. The ban on Kurdish at home was related to enforced patterns of learning and communication in a foreign tongue (Turkish), which they defined as oppressive. In Austria they understood that their poor knowledge of another foreign tongue (German) was a cause of their marginal position. However, they believed that improving their German could change this situation. Such a change of "grammar" is often the difference between a retrospective and prospective view.

Our discussions revealed that one subject position was often expressed in the terminology, symbolism, and arguments of another. Thus, for example, a viewpoint on gender could be argued in the language of nationalism, or religion could be legitimized as culture.

From these strategies we inferred three points:

1. Particularly those subject positions that are currently the most contested such as gender, culture, ethnicity, religion, and nation are in the process of change. This creates new commonalities and discrepancies between them.

2. The new processes of identity in which the discussants found themselves have made certain positions and keywords (e.g., culture) particularly favourable with them. Thus the justification of an opinion may undergo shifts according to a change of the given context. Among a group of academics and a generally heterogeneous audience the youngsters may have found it advantageous to explain their own situatedness by stating, "this is my culture!"

3. The negative stereotypes with which they are confronted in Austria force these youths to respond accordingly and to identify themselves so as to strengthen their self-perceptions. 
The change of perspective between the "constructivism of the observer" and the "essentialism of the participant," which is addressed in our theory section, was a tangible feature of the group discussions. In cases where people tried to legitimize a political standpoint they adopted an uncritical, essentialist attitude toward their "corporate identity." However, in cases where issues were raised that did not personally affect one or more discussants, they voiced a constructivist-critical distance vis-à-vis the topic.

\section{Directions for Further Research}

The number of theoretical studies on the meanings of identity greatly surpasses the amount of effort that has gone into empirical studies on the subject. More empirical research is therefore needed not only to examine the theoretical concepts but aiso to obviate the stance of a premature normativism, which we addressed above.

The theoretical dichotomy of essentialism versus constructivism also needs to be rethought. Strategies of mediation, as expressed in the metaphors of observer/participant contribute to more constructive thought. Analysts of identity must include the apparent paradox that identities are impossible but necessary (Hall, 1996).

The theoretical literature more or less agrees with three factors: (a) identities are only periodically fixed; (b) they materialize in the form of intersecting subject positions; and (c) they are dependent on specific ways of identification. The intersections in themselves need more investigation and grounding in empirical research. In order to analyse the formation and significance of a situated hierarchy among subject positions, we must understand the aims and aspirations of social actors in each case.

As we have seen in our discussions, the strategies of identity employed by these young people who are socially, culturally, and legally marginalized make us aware of how much these strategies are informed by the politics of identity practised by the dominant majority. In order to understand the relational and dialectical character of the self and other we need to engage in comparative studies of majority and minority identities.

Finally, as in all areas of research, we must consider an important factor, that is, in order to avoid preconceived ideas to determine the outcome of a study (e.g., "young people in diaspora form new identities") a meta-reflexive question must be asked: Is it possible to conceive of intersubjective processes without using the politically charged construct 
called identity? This question becomes even more relevant when we consider the fact that programmatic questions such as "beyond culture?" or "beyond belonging?" have recently become popular as titles for books and articles. These questions should, therefore, be appended with that of "beyond identity?"

\section{Acknowledgements}

This article was translated from German by Maxim Anderson and Heidi Armbruster. It first appeared: "Die notwendige Unmöglichkeit. Identitätsprozesse von Jugendlichen unterschiedlicher Herkunft in Wien", in Berghold, Menasse, Ottomeyer (Eds.) (2000) Trennlinien. Imagination des Fremden und Konstruktion des Eigenen. 149-178 Klagenfurt/Celovec: Drava Verlag, This study was carried out as part of the research program Xenophobia, commissioned by the Austrian Federal Ministry of Science. The authors would like to thank the ministry for financing the translation of the article.

\section{Notes}

1 Black feminists and feminists of colour introduced the notion "politics of location" which reflects differences among women.

2 The politics of identity have a much longer history. Recent debates refer to contemporary developments. For an early reference to "identity politics" (in 1963) see Goffman (1998).

3 According to Benhabib (1999) these are ethnic, cultural and religious forms of separatism (e.g. the Québécois in Canada) and the movements for multi- or pluricultural forms of government (e.g., ETA, IRA, and PKK)

4 These discourses have been described frequently; we therefore simply mention the landmarks: A "difference versus equality" paradigm took hold in the late 60s; this was later replaced by "the politics of identity versus politics of distribution." The orientation towards differences among women or "differences within" occurred in the 80s; the criticisms by Black feminists and women of color effectuated a still-present pluralization within feminism and a special concern with "female identity."

5 We were able to observe this change of perspective among the participants in our group discussions.

6 Roland Robertson coined the term "globalization" for these developments. See Robertson (1993).

7 Appadurai (1996) described this situation in terms of "scapes". Ethnoscapes replace traditional territorial entities such as community, village, locality. These became landscapes of social interaction.

8 For the concept of intersections of systems of difference see Abu-Lughod (1991); for the notion of intersections see Kossek (1997) and the contributions to Schein \& Strasser (1997); for postcolonial theories see Williams \& Chrisman (1994); Gandhi (1998).

9 This was said by a young man who responded to our note of thanks after a discussion by saying: "It was a pleasure; we have only made clear who we are!"

10 We chose group discussions as a method of formal data collection because they actuated and made visible how opinions are formed within the dynamic of a group. In addition, this method enabled us to gain insights about how identities are produced in everyday social practices. These discussions took place between September and December 1998.

11 The basic thrust of these questions was: you have known each other for several weeks; how do you like it here, how do you spend your time together, what are your experiences like?

12 (1) Subject positions: can you think of situations where it becomes important where you are from? Are there situations when it becomes important whether you are a woman or a man? 
Does religion play a role for you?(2) Locations: do you like living in Vienna? What do you do in Vienna, where do you spend most of your time? (3) Perspectives: what are you planning to do after the course?

13 We can only present excerpts of the discussions here. A more elaborate presentation may be found in our final report.

14 Participants' names are pseudonyms.

15 Italicized words refer to the expressions used by the discussants in the interviews. The discussions were held in German. We made some corrections to the language where relevant.

16 See Note 9.

17 Some academic literature has called for the necessity to privatize religion. See e.g. Habermas, 1993.

18 Honour in this context means prestige (seref) as well as a sexualized form of respectability (namus). See Strasser (1995).

19 The hierarchical structure of identity, rather than its postmodern arbitrariness, is emphasized in theories which are based on Gramsci's "hegemony" and Althusser's "interpellation". See Laclau \& Mouffe (1985); Mouffe (1999); Gürses (1998).

20 We observed that young people who had been in Austria for a long time were much more conversant in adopting these strategies.

\section{References}

Abu-Lughod, Lila (1991). Writing against Culture, in: Richard G. Fox (Hg.), Recapturing Anthropology. Working in the Present. Santa Fe, New Mexico, 137-162.

Anderson, Benedict (1988). Die Erfindung der Nation. Zur Karriere eines folgenreichen Konzepts. Frankfurt/Main, New York.

Appudarai, Arjun (1996). Modernity at Large. Cultural Dimensions of Globalization. Minnesota, Minneapolis.

Balibar, Etienne (1990a). Gibt es einen "Neo-Rassismus"?, in: Etienne Balibar/Immanuel Wallerstein, Rasse Klasse Nation. Ambivalente Identitäten. Hamburg/Berlin, 23-28.

Balibar, Etienne (1990b). Die Nation-Form: Geschichte und Ideologie, in: Etienne Balibar/ Immanuel Wallerstein, Rasse Klasse Nation. Ambivalente Identitäten. Hamburg/Berlin, 107-130.

Barth, Fredrik (1969). Ethnic Groups and Boundanies. The Social Organisation of Culture Difference. Bergen.

Bauböck, Rainer (1996). Cultural Minority Rights for Immigrants, in: International Migration Review, vol. 30, No. 1, 203-250.

Bauböck, Rainer (1998). Minderheiten im Übergang. Zur Assimilation von Einwanderem, in: STIMME von und für Minderheiten. Wien, Innsbruck, 14-16.

Beck, Ulrich (1998). Wie wird Demokratie im Zeitalter der Globalisierung möglich? - Eine Einleitung, in: Ulrich Beck (Hg.), Politik der Globalisierung. Frankfurt/Main, 7-66.

bell hooks (1984). Feminist Theory: From Margin to Center. Boston.

Benhabib, Seyla (1999). Kulturelle Vielfalt und demokratische Gleichheit. Politische Partizipation im Zeitalter der Globalisierung. Frankfurt/Main.

Benhabib, Seyla et al. (1994). Der Streit um Differenz. Feminismus und Postmoderne in der Gegenwart. Frankfurt/Main.

Bhabha, Homi (Hg.) (1990). Nation and Narration. London, New York.

Bielefeldt, Heiner (1998). Philosophie der Menschenrechte. Grundlagen eines weltweiten Freiheitsethos. Darmstadt.

Bohnsack, Ralf (1989). Generation, Milieu und Geschlecht. Ergebnisse aus Gruppendiskussionen mit Jugendlichen. Opladen 
Bohnsack, Ralf (1993). Rekonstruktive Sozialforschung. Einführung in Methodologie und Praxis qualitativer Forschung. Opladen

Brah, Avtar (1993). Difference, diversity and differentiation, in: James Donald/Ali Rattansi (Hg.), ,Race', Culture and Difference. London, Newbury Park, New Delhi, 126-145.

Braidotti, Rosi (1994). Nomadic Subjects. Embodiment and Sexual Difference in Contemporary Feminist Theory. New York.

Bruck, Peter A./Günther Stocker (1996). Die ganz normale Vielfältigkeit des Lesens. Zur Rezeption von Boulevardzeitungen. Münster.

Butler, Judith (1991). Das Unbehagen der Geschlechter. Frankfurt/Main.

Butler, Judith (1997). Körper von Gewicht. Frankfurt/Main.

Çaglar, Ayse S. (1990). Das Kultur-Konzept als Zwangsjacke in Studien zur Arbeitsmigration, in: Zeitschrift für Türkeistudien 1, 93-103.

Çinar, Dilek (1996). Unüberwindbare Fremdheit? Immigration und die Politik der Differenz, in: Brigitte Fuchs/Gabriele Habinger ( $\mathrm{Hg}$.), Differenzen, Machtverhältnisse und Solidarität zwischen Frauen. Wien, 161-170.

Çinar, Dilek (1999a). Die "neuen" Einwanderer Europas: Fremde auf Dauer? Eine Untersuchung der Quellen von Fremdheit im Kontext der Nachkriegseinwanderung. (unveröffentlichte Dissertation) Wien.

Çinar, Dilek (1999b). "Alter" Rassismus im "neuen" Europa? Anmerkungen zur Novität des Neo-Rassismus, in: Susanne Rieser/Sabine Strasser (Hg.), Innen - Außen - Zwischendrin. Perspektiven feministischer Forschung und Lehre 2000. Dokumentation der 5.

Österreichischen Wissenschafterinnentagung. Wien, 17-28.

Derrida, Jaques (1986). Positionen. Graz, Wien.

Dittrich, Eckhard J./Frank-Olaf Radtke (1990). Der Beitrag der Wissenschaften zur Konstruktion ethnischer Minderheiten, in:, Eckhard J. Dittrich./Frank-Olaf Radtke (Hg.), Ethnizität. Wissenschaft und Minderheiten. Opladen, 11-40.

Foerster, Heinz von et al. (1997). Einführung in den Konstruktivismus. München.

Friedman, Jonathan (1997). Global Crises, the Struggle for Cultural Identity and Intellectual Prokbarrelling: Cosmopolitans versus Locals, Ethnics and Nationals in an Era of Dehegemonisation. In: Pnina Werbner/Tariq Modood (Hg.): Debating Cultural Hybridity. London, New Jersey, 70-89.

Gandhi, Leela (1998). Postcolonial Theory. A Critical Introduction. Edinburgh.

Geertz, Clifford (1996). Welt in Stücken. Kultur und Politik am Ende des 20. Jahrhunderts. Wien.

Goffman, Erving (1998). Stigma. Über Techniken der Bewältigung beschädigter Identität. Frankfurt/Main.

Grossberg, Lawrence et al. (1994). Cultural Studies. Eine Intervention. IKUS-Lectures 17/18. Wien.

Grossberg, Lawrence et al. (Hg.) (1992). Cultural Studies. London, New York.

Gürses, Hakan (1994). Wechselspiel der Identitäten. Bemerkungen zum Minderheitenbegriff, in: SWS-Rundschau 4. Wien, 353-368.

Gürses, Hakan (1996). Libri catenati. Eine historisch-philosophische Untersuchung der Sekundärdiskurse. Wien.

Gürses, Hakan (1998). "Ich bin Niemand". Identität - von Odysseus zu Minderheiten, in: Peter Bettelheim et al. (Hg.), Kunstreiten auf dem Lippizaner der Identität. Beiträge zu Kultur und Mentalität. Klagenfurt, Wien, Ljubljana, Sarajevo, 35-47.

Gutmann, Amy (Hg.) (1993). Multikulturalismus und die Politik der Anerkennung. Frankfurt/ Main.

Haas, Barbara/Ella Scheibelhofer (1998). Typenbildung in der qualitativen Sozialforschung. Eine methodologische Analyse anhand ausgewählter Beispiele. Wien.

Habermas, Jürgen (1985). Der philosophische Diskurs der Moderne. Frankfurt/Main. 
Habermas, Jürgen (1993). Anerkennungskämpfe im demokratischen Rechtsstaat, in: Amy Gutmann (Hg.), Multikulturalismus und die Politik der Anerkennung. Frankfurt/Main, 147196.

Hall, Stuart (1994). Rassismus und kulturelle Identität. Ausgewählte Schriften 2. Hamburg.

Hall, Stuart (1996). Introduction: Who Needs 'Identity'?, in: Stuart Hall/Paul du Gay (Hg.), Questions of Cultural Identity. London, Thousand Oaks, New Delhi, 1-17.

Haraway, Donna (1995). Ein Manifest für Cyborgs. Feminismus im Streit mit den Technowissenschaften, in: Carmen Hammer/Immanuel Stieß (Hg.), Die Neuerfindung der Natur. Primaten, Cyborgs und Frauen. Frankfurt, New York, 33-72.

Heller, Agnes (1995). Ist die Moderne lebensfähig? Frankfurt, New York.

Hill Collins, Patricia (1996). Ist das Persönliche politisch genug? Afrikanisch-amerikanische Frauen und feministische Praxis, in: Brigitte Fuchs/Gabriele Habinger ( $\mathrm{Hg}$.), Feminismen \& Rassismen. Differenzen, Machtverhältnisse und Solidarität zwischen Frauen. Wien, 6791.

Kehl-Bodrogi, Krisztina (1989). Das Alevitum in der Türkei: Zur Genese und gegenwärtigen Lage einer Glaubensgemeinschaft, in: Peter A. Andrews (Hg.), Ethnic Groups in the Republic of Turkey. Wiesbaden.

Klinger, Cornelia (1995). Über neuere Tendenzen in der Theorie der Geschlechterdifferenz, in: Deutsche Zeitschrift für Philosophie 43. Berlin, 801-814.

Knorr-Cetina, Karin (1989). Spielarten des Konstruktivismus - Einige Notizen und Anmerkungen, in: Soziale Welt, Jg. 40, Heft $1 / 2$.

Kossek, Brigitte (1997). Überschneidungen, Zwischenräume \& Grenzziehungen, in: Gerlinde Schein/Sabine Strasser ( $\mathrm{Hg}$.), Intersexions. Feministische Anthropologie zu Geschlecht, Kultur und Sexualität. Wien, 177-230.

Kymlicka, Will (1995). Multicultural Citizenship. A Liberal Theory of Minority Rights. Oxford. Laclau, Ernesto (1994). Universalismus, Partikularismus und die Frage der Identität, in: Mesotes. Zeitschrift für philosophischen Ost-West-Dialog, 3. Wien, 287-299.

Laclau, Ernesto (1997). Inklusion, Exklusion und die Logik der Äquivalenz, in: Peter Weibel/ Slavoj Zizek (Hg.), Inklusion: Exklusion. Probleme des Postkolonialismus und der globalen Migration. Wien, 45-74.

Laclau, Ernesto/Chantal Mouffe (1985). Hegemony \& Socialist Strategy. Towards a Radical Democratic Politics. London, New York.

Lamnek, Siegfried (1993). Qualitative Sozialforschung, Bd.2: Methoden und Techniken. Weinheim.

Littig, Beate/Claire Wallace (1997). Möglichkeiten und Grenzen von Fokus-Gruppendiskussionen für die sozialwissenschaftliche Forschung. Wien.

Lutter, Christina/Markus Reisenleitner (1998). Cultural Studies. Eine Einführung. Wien.

Mohanty, Chandra T. (1988). Aus westlicher Sicht: Feministische Theorie und koloniale Praxis, in: beiträge zur feministischen theorie und praxis 23, 149-162.

Moore, Henrietta (1994). The divisions within. Sex, Gender and Sexual Difference, in: Henrietta

Moore, A Passion for Difference. Essays in Anthropology and Gender. Cambridge/Oxford, 827.

Mouffe, Chantal (1997). Inklusion/Exklusion: Das Paradox der Demokratie, in: Peter Weibel/ Slavoj Zizek (Hg.), Inklusion: Exklusion. Probleme des Postkolonialismus und der globalen Migration. Wien, 75-90.

Mouffe, Chantal (1999). Hegemony, Power and the Political Dimension of Culture, in: Bundesministerium für Wissenschaft und Verkehr/Internationales Forschungszentrum Kulturwissenschaften (Hg.), The Contemporary Study of Culture. Wien, 47-52.

Neumann-Braun, Klaus/Amulf Deppermann (1998). Ethnographie der Kommunikationskulturen Jugendlicher. Zur Gegenstandskonzeption und Methodik der Untersuchung von PeerGroups, in: Zeitschrift fur Soziologie 27 (4), 239-255.

Räthzel, Nora (1999). Hybridität ist die Antwort, aber was war nochmal die Frage? In: Brigitte 
Kossek (Hg.), Gegen-Rassismen. Berlin, Hamburg, 204-219.

Rich, Adrienne (1984). Blood, Bread, and Poetry. London.

Robertson, Roland (1993). Globalization. Social Theory and Global Culture. London.

Saussure, Ferdinand de (1967). Grundfragen der allgemeinen Sprachwissenschaft. Berlin.

Schein, Gerlinde/Sabine Strasser (Hg.) (1997). Intersexions. Feministische Anthropologie zu Geschlecht, Kultur und Sexualität. Wien.

Singer, Mona (1997). Fremd. Bestimmung. Zur kulturellen Verortung von Identität. Tübingen. Stolcke, Verena (1996). Talking Culture. New Boundaries, New Rhetorics of Exclusion in

Europe, in: Current Anthropology 36 (1), 1-13.

Strasser, Sabine (1995). Die Unreinheit ist fruchtbar! Grenzüberschreitungen in einem türkischen Dorf am Schwarzen Meer. Wien.

Strasser, Sabine (forthcoming): Dynamiken der Deterritorialisierung - oder wie Bewegung in die Sozialanthropologie kam. In: Judith Schlehe ( $\mathrm{Hg}$.), Interkulturelle

Geschlechterforschung. Identitäten, Imaginationen, Repräsentationen. Frankfurt/Main, New York.

Taguieff; Pierre-André (1991). Die ideologischenMetamorphosen des Rassismus und die Krise des Antirassismus, in: Uli Bielefeld ( $\mathrm{Hg}$.), Das Eigene und das Fremde: neuer Rassismus in der alten Welt? Hamburg, 221-268.

Taylor, Charles (1993). Die Politik der Anerkennung, in: Amy Gutmann (Hg.), Multikulturalismus und die Politik der Anerkennung. Frankfurt/Main, 13-78.

Vorhoff, Karin (1995). Zwischen Glaube, Nation und neuer Gemeinschaft. Alevitische Identität in der Türkei in der Gegenwart. Berlin.

Werbner, Pnina (1997). Introduction: The Dialectics of Cultural Hybridity, in: Pnina Werbner/ Tariq Modood (Hg.) (1997), Debating Cultural Hybridity. Multi-Cultural Identities and the Politics of Anti-Racism. Londen, New Jersey, 1-24.

Werbner, Pnina/Tariq Modood (Hg.) (1997). Debating Cultural Hybridity. Multi-Cultural Identities and the Politics of Anti-Racism. Londen, New Jersey.

Williams, Patrick/Laura Chrisman (Hg.) (1994). Colonial Discourse and Post-Colonial Theory. A Reader. New York.

Wodak, Ruth et al. (1998). Zur diskursiven Konstruktion nationaler Identität. Frankfurt/Main. Young, Iris Marion (1990). Justice and the Politics of Difference. Princeton, New Jersey.

Zolberg, Aristide (1996). Immigration and Multiculturalism in the Industrial Democracies, in: Rainer Bauböck et al. (Hg.), The Challenge of Diversity. Integration and Pluralism in Societies of Immigration. Aldershot, 43-66. 